\title{
KEANEKARAGAMAN JENIS BURUNG DI KAWASAN HUTAN LINDUNG GUNUNG SIRIMAU
}

THE DIVERSITY OF BIRDS IN THE PROTECTED FOREST AREA OF SIRIMAU

John . F. Sahusilawane

Jurusan Kehutanan Fakultas Pertanian Universitas Pattimura Ambon

Jl. Ir.M.Putuhena Kampus Poka Ambon 97237

Penulis korespondensi email : johnsahusilawane9@gmail.com

\begin{tabular}{|l|l|}
\hline Diterima : 6 Januari 2018 & Disetujui : 22 Februari 2018 \\
\hline
\end{tabular}

\section{Intisari}

Penelitian ini dilakukan untuk mengetahui komposisi keragaman burung dan stadium serta komposisi vegetasi, untuk mengetahui variabel-variabel yang paling berpengaruh terhadap keragaman burung di hutan lindung Sirimau, Penelitian ini dilakukan selama tiga bulan sejak bulan September 2015 sampai November 2015. Pengamatan burung dan variabel habitatnya dilakukan dengan menggunakan metode Point Count, dan menemukan tiga puluh titik pengamatan di setiap lokasi, dengan teralis $30 \mathrm{~cm}$ dan jarak plot $200 \mathrm{~m}$. Hasil analisis burung dan vegetasi di hutan lindung Gunung Sirimau menunjukkan bahwa, jenis burung didominasi oleh Mata Merah (Aplonis Motalica), dan lebih dari 50 jenis vegetasi yang ada dilokasi penelitian, didominasi oleh jenis buah-buahan.

Kata kunci: keragaman burung, keragaman vegetasi, dan hutan lindung.

\begin{abstract}
This study was conducted to determine the composition of bird diversity and vegetation stages and composition, to determine the variables that most influence the diversity of birds in protected forests Sirimau, This study was conducted for three months from September 2015 to November 2015. Bird observations and habitat variables performed using the Point Count method, and found thirty observation points at each location, with 30 $\mathrm{cm}$ trellis and $200 \mathrm{~m}$ plot distance. The analysis of birds and vegetation in Sirimau mountain forests shows that, bird species are dominated by Red Eye (Aplonis Motalica), and more than 50 species of vegetation exist in the research location, dominated by fruits.
\end{abstract}

Keywords: bird diversity, vegetation diversity, and protected forest. 


\section{PENDAHULUAN}

Sumber kekayaan alam baik hayati maupun non hayati yang terkandung di Propinsi Maluku mempunyai peranan penting bagi kehidupan manusia baik ditinjau dari segi ekonomi, penelitian, pendidikan dan kebudayaan, maupun untuk kepentingan rekreasi dan parawisata. Satwa liar khususnya burung (Aves) mempunyai peranan penting dalam meningkatakan produktifitas pertanian, perkebunan maupun kehutanan. Secara ekologis satwa burung berperan penting dalam proses penyerbukan dan penyebaran biji ke berbagai tempat. Selain itu burung merupakan salah satu dari sedikit kelompok hidupan liar yang memiliki sifat-sifat yang mendukung yaitu hidup diseluruh habitat, peka terhadap perubahan lingkungan dan taksonomi serta penyebarannya telah cukup memadai. Penelitian yang telah dilakukan selama ini menunjukkan bahwa keragaman jenis burung dapat mencerminkan tingginya keanekaragaman hayati kehidupan liar lainnya (Sujatnika, 1995). Sifat burung sangat peka terhadap perubahan lingkungan maka keberadaan jenis - jenis burung dalam suatu wilayah dapat dikatakan sebagai bio-indikator kondisi lingkungan. Oleh karena itu maka pengkajian mengenai keanekaragaman jenis burung dapat digunakan sebagai acuan pengelolaan kawasan secara menyeluruh.

Propinsi Maluku terdiri dari 1.027 buah pulau besar maupun kecil, sehingga lebih dikenal dengan julukan "Propinsi seribu pulau“. Terletak diwilayah oriental yang berada disebelah timur garis Wallacea dan disebelah barat garis Mayr. Oleh karena itu flora dan fauna di Maluku tergolong dalam kesatuan biogeografis Wallacea, yang memiliki flora dan fauna yang khas (endemik), tetapai juga mengandung unsur-unsur dari wilayah Oriental dan Australesia. Kondisi demikian menyebabkan Maluku memiliki koleksi flora dan fauna endemik yang sangat penting dan juga terutama ditinjau dari segi keanekaragaman hayatinya.

Khusus untuk keragaman jenis burung, maka Maluku memiliki 348 jenis burung dengan 90 jenis merupakan spesies endemik Maluku. Jenis-jenis ini tersebar di 5 DBE (Daerah Burung Endernik), dengan jumlah spesies burung sebaran terbatas sebanyak 116 jenis (Sujatnika, 1995). Khusus untuk paruh bengkok (kakatua dan nuri) di Maluku terdapat 32 jenis dan 12 jenis diantaranya tidak ada di tempat lain kecuali dari Maluku. BKSDA Maluku, (2006) dalam Badarudin. E (2007). 
Kekayaan sumberdaya alam hayati khususnya burung, cukup membanggakan disatu sisi, namun disisi lain menuntut tanggung jawab untuk tetap mempertahankan keberadaannya. Untuk itu upaya perlindungan dan pelestarian akan menjadi skala prioritas untuk segera dilakukan dalam rangka melestariakan keanekaragaman sumberdaya alam hayati dan ekosistemnya.

Satwaliar mengalami tekanan dari dua ancaman paling utama yaitu pengrusakan habitat dan perburuan tanpa batas (Djuwantoko, 2000). Oleh karena itu upaya konservasi satwaliar perlu dilakukan, karena jika tidak maka ancaman kepunahan akan terbuka lebar di depan kita.

Salah satu upaya konservasi yang dapat dilakukan yaitu dengan menjaga dan memperkuat pola-pola pemanfaatan sumberdaya alam secara tradisional. Hasil penelitian ini diharapkan dapat : Mengetahui keanekaragaman jenis burung berdasarkan jenis pakannya di Hutan Lindung Gunung Sirimau; Mengetahui Kerapatan Jenis burung di Hutan Lindung Gunung Sirimau; Mengetahui Struktur dan komposisi vegetasi pada habitatnya di Hutan Lindung Gunung Sirimau.

\section{METODE PENELITIAN}

Penelitian dilakukan pada bulan September 2015 sampai dengan November 2015. Sedangkan lokasi penelitian dilakukan di kawasan hutan Lindung Gunung Sirimau Objek penelitian adalah : Komunitas burung di di kawasan hutan Lindung Gunung Sirimau Alat yang digunakan selama penelitian adalah : (1) Binokuler , (2) Buku panduan lapangan pengenalan burung - burung di Sumatera, Kalimantan, Jawa dan Bali karangan John MacKinnon. (1992), (3) Global Positioning System (GPS), (4) Range Finder , (5) Kamera, (6) Alat Tulis, (7) Peta lokasi penelitian, (8) Komputer

\section{Pengumpulan Data}

Untuk memenuhi tujuan penelitian maka data yang akan dikumpulkan adalah data primer yang diambil secara langsung di lapangan serta melalui perhitungan dan data sekunder yang diambil dari berbagai sumber.

Data primer :

1. Data jumlah jenis dan jumlah individu burung pada setiap lokasi penelitian

2. Data keanekaragaman dan kerapatan jenis burung pada setiap lokasi

3. Data biotik yaitu data habitat berupa kerapatan vegetasi, frekuensi vegetasi, dominansi vegetasi, keanekaragaman jenis vegetasi, luas bidang dasar vegetasi, tinggi pohon rata - rata, 
jumlah strata, cover, ground cover, tinggi tajuk.

4. Data abiotik berupa faktor fisik yaitu jarak dari rumah penduduk, suhu, ketinggian tempat.

\section{Prosedur Pelaksanaan Penelitian}

Pengambilan Data Jenis Burung

Metode Pengumpulan data dilakukan dengan membuat 1 jalur pada lokasi penelitian sehingga terdapat 30 titik pengamatan di lokasi penelitian.

Prosedur pengambilan data menggunakan metode Point Count (Bibby, dkk., 2000), langkah - langkah yang dilakukan :

1. Menentukan jarak antara titik pengamatan secara sistimatis yaitu sepanjang 200 meter.

2. Menentukan radius plot pengamatan (30 meter) dengan memberi tanda pada batas plot.
Data Sekunder :

1. Peta lokasi penelitian

2. Deskripsi kondisi fisik secara umum lokasi penelitian

Data sekunder ini didapatkan dari penelusuran pustaka dan internet.

3. Melakukan pengamatan sebanyak dua kali yang dilakukan pada pagi hari mulai pukul 05.30 - 11.00 WIT, dan dilanjutkan sore hari pada pukul 15.00 - 17.30 WIT. Pengamatan tidak dilakukan pada siang hari karena aktivitas burung pada siang hari kurang aktif. Pengamatan dan pencatatan dilakukan selama 10 menit setelah pengamat tiba di titik pengamatan untuk mengurangi gangguan terhadap aktifitas burung karena kedatangan pengamat .

4. Mencatat jenis dan jumlah burung yang ada di dalam plot pengamatan.

Gambar penempatan titik menurut Metode Point Count dapat dilihat pada gambar 3.2 berikut ini :

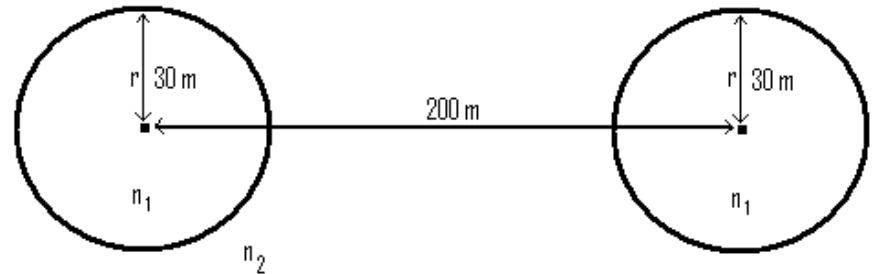

Gambar 3.2. Penempatan plot metode point count

$$
\begin{array}{ll}
\text { dimana : } & \mathbf{r}=\text { jari-jari band (30 meter) } \\
& \mathbf{n}=\text { Burung didalam band } \\
& \text { jarak antar band }=\mathbf{2 0 0} \text { meter }
\end{array}
$$

\section{Pengambilan Data Vegetasi}


Pengambilan data vegetasi di lokasi penelitian dengan menempatkan titik pengamatan sama dengan titik pengamatan burung, jarak antar titik pengamatan adalah 200 meter dan di setiap lokasi

\section{Analisis Data}

Dalam pengamatan burung dan pengukuran vegetasi digunakan tabel bantu sebagai berikut :

Tabel 2. Tabel Bantu Pengamatan burung

\begin{tabular}{|l|l|l|l|}
\hline No titik & Jenis Burung & Jumlah Individu & Keterangan \\
\hline & & & \\
& & & \\
& & & \\
\hline
\end{tabular}

Tabel 3. Tabel Bantu Pengamatan Vegetasi

\begin{tabular}{|c|l|l|l|l|l|}
\hline $\begin{array}{c}\text { No } \\
\text { titik }\end{array}$ & Jenis & Jumlah & Tinggi & Diameter & Keterangan \\
\hline
\end{tabular}

Analisis Data Burung

Indeks Keanekaragaman jenis burung Shannon - Wienner digunakan untuk mengetahui keanekaragaman jenis burung pada tiap lokasi (Magurran, 1988),

$$
\mathrm{H}^{\prime}=-\sum p i \ln p i
$$

Keterangan :

$H^{\prime}=$ indeks keanekaragaman ShannonWienner

$P i=$ proporsi kelimpahan dari total sampel sejumlah i jenis $(\mathrm{Ni} / \mathrm{N})$

$$
\begin{aligned}
& \mathrm{Ni}=\text { jumlah burung jenis ke } \mathrm{i} \\
& \mathrm{N}=\underset{\text { jumlah total individu semua jenis }}{\text { burung }}
\end{aligned}
$$

Untuk mengetahui kelimpahan burung disetiap lokasi penelitian diukur dari jumlah dan kerapatan individu burung untuk tiap - tiap tipe habitat dan untuk seluruh $\operatorname{area}(\mathrm{N} / \mathrm{Ha})$.

$$
\text { Kerapatan } \quad=\quad \frac{\text { Jumlah Individu suatu spesies burung }}{\text { Luas seluruh petak }}
$$

Analisis Data Vegetasi 
Data vegetasi dianalisis untuk mengetahuinya digunakan formula diketahui kerapatannya dan indeks Indeks Keanekaragaman Jenis keanekaragaman jenisnya. Untuk vegetasi

$$
\mathrm{H}^{\prime}=-\sum p i \ln p i
$$

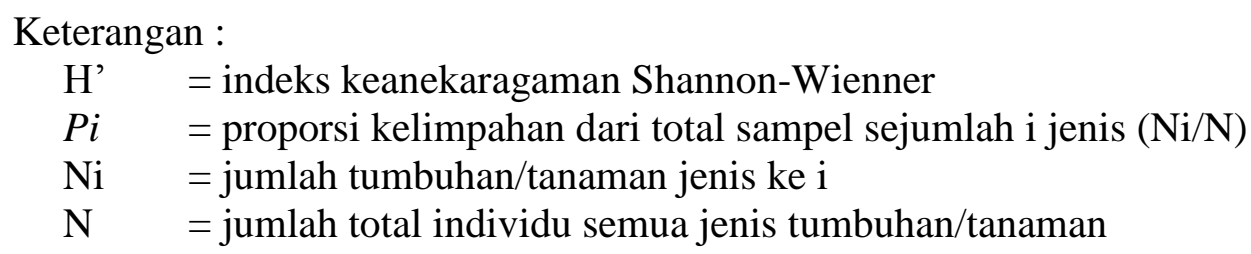

Kerapatan $\quad=\frac{\text { Jumlah Individu suatu spesies }}{\text { Luas seluruh petak }}$

$$
\text { Kerapatan Relatif }=\frac{\text { Kerapatan Suatu Jenis }}{\text { Kerapatan Seluruh Jenis }} \times 100 \%
$$$$
\text { Frekwensi } \quad=\quad \frac{\text { Jumlah plot contoh ditemukan suatu jenis }}{\text { Jumlah seluruh plot contoh }}
$$$$
\text { Frekwensi Relatif }=\frac{\text { Frekwensi Suatu Jenis }}{\text { Kerapatan Seluruh Jenis }} \times 100 \%
$$$$
\text { Dominansi } \quad=\frac{\text { Jumlah Luas Bidang Dasar Suatu Jenis }}{\text { Luas Seluruh plot contoh }}
$$

$$
\text { Dominansi Relatif }=\frac{\text { Dominansi Suatu Jenis }}{\text { Dominansi Seluruh Jenis }} \quad \text { X } 100 \%
$$

INP (untuk semai dan pancang) $=$ Kerapatan Relatif + Frekuensi Relatif

INP (untuk tiang dan pohon $)=$ Kerapatan Relatif + Frekuensi Relatif + Dominasi Relatif

\section{Penutupan cover dan ground cover}

Pengukuran ini ditaksir dengan menggunakan tabung okuler yang beriri rambut silang pada salah satu ujungnnya. Pengamat berjalan di garis traksek (yang digunakan untuk mengitung karapatan semak dan tumbuhan bawah), plus atau minus masing - masing menunjukan ada atau tidaknya vegetasi hijau di titik interkseksi dari rambut silang. Hal yang sama dilakukan untuk penutupan semak dan tumbuhan bawa, hanya saja pengamat mengarahkan pandangannya kebawah dengan ketinggian $\pm 1 \mathrm{~m}$. Penutupan tajuk 
pohon, penutupan semak dan tumbuhan bawah dihitung dengan menggunakan rumus, (Noon,1981)

$$
\mathrm{C}=(\mathrm{P} / 12) \times 100 \%
$$

Keterangan :

$\mathrm{C}=$ Penutupan tajuk pohon,semak dan tumbuhan bawah.

$\mathrm{P}=$ Jumlah terlihatnya hijauan vegetasi rambut silang tabung okuler.

\section{HASIL DAN PEMBAHASAN}

\section{Kekayaan Jenis Burung}

Berdasarkan jenis pakan maka burung - burung pada hutan Lindung Gunung Sirimau didominasi oleh pemakan buah dan biji sebanyak 12 jenis dan diikuti dengan jenis pemakan serangga 4 jenis serta pemakan buah 3 jenis, buah biji dan serangga 2 jenis, penghisap madu 1 jenis, pemakan serangga dan ikan juga 1 jenis. Dominasi jenis burung pemakan buah di hutan Lindung Gunung Sirimau disebabkan karena pada hutan Lindung Gunung Sirimau banyak didominasi oleh jenis tanaman buah - buahan.

Tabel 3. Keanekaragaman Jenis Burung Pada Lokasi Hutan Lindung Gunung Sirimau

\begin{tabular}{|c|c|c|c|c|}
\hline NO & NAMA JENIS & NAMA ILMIAH & FAMILLI & JENIS PAKAN \\
\hline 1 & $\begin{array}{l}\text { Betet Kelapa Paruh } \\
\text { Besar }\end{array}$ & $\begin{array}{l}\text { Tanygnathus } \\
\text { megalorynchas }\end{array}$ & Psittacidae & Buah dan Biji \\
\hline 2 & Burung Hujan & Motalica flava & Maotacillidae & Serangga \\
\hline 3 & Burung siang & Philemon subcorniculatas & Meliphagidae & Buah dan Biji \\
\hline 4 & $\begin{array}{l}\text { Cui } \\
\text { Fkor Ikan/Lavano }\end{array}$ & Collocalia esculenta & Merophidae & Serangga \\
\hline 5 & layang api & Megapodius reinwardtii & Hirundinidae & Serangga \\
\hline 6 & Elang Bondoi & Haliastur indus & Acciptiridae & $\begin{array}{c}\text { Daging } \\
\text { Serangga buah dan }\end{array}$ \\
\hline 7 & $\begin{array}{l}\text { Kacamata Ambon } \\
\text { Kakatua }\end{array}$ & Zosterops kuehni & Zosteropidae & biji \\
\hline 8 & $\begin{array}{l}\text { Hijau/Bayan } \\
\text { Kakatua Putih }\end{array}$ & Eclectus rotarus & Psittacidae & Buah dan Biji \\
\hline 9 & Jambul Kuning & Cacatua galerita & Psittacidae & Buah dan Biji \\
\hline 10 & $\begin{array}{l}\text { Lawa lawa } \\
\text { Maleo/gosong kaki } \\
\text { merah }\end{array}$ & Collocalia esculenta & Megapodidae & $\begin{array}{c}\text { Serangga } \\
\text { Buah, Biji dan } \\
\text { Serangga }\end{array}$ \\
\hline 12 & Mata Merah & Aplonis motalica & Anhingidae & Buah dan Biji \\
\hline 13 & Merpati Hutan & Ptilinopus superbus & Columbidae & Buah dan Biji \\
\hline 14 & Nuri Merah & Eos bornea & Psittacidae & Buah dan Biji \\
\hline 15 & Nuri Raja & Alisterus amboinensis & Psittacidae & Buah dan Biji \\
\hline 16 & Perkici dagu merah & Charmocyna piacentis & Psittacidae & Buah \\
\hline 17 & Perkici Pelangi & Trichoglossus haematodus & Psittacidae & Buah \\
\hline 18 & Pombo & Ducula concinna & Columbidae & Buah dan Biji \\
\hline 19 & Pombo Hijau & Ducula forsteni & Columbidae & Buah dan Biji \\
\hline
\end{tabular}




\begin{tabular}{llllc}
\hline 20 & Pombo Putih & Ducula Bicolor & Columbidae & Buah dan Biji \\
21 & Raja Udang & Halcyon chloris & Alcedinidae & Serangga dan ikan \\
22 & Sesap Madu Sriganti & Nectarinia jugalaris & Netarinidae & Madu \\
23 & Srigunting lencana & Dicrurus bracteatus & Dicrudidae & Serangga \\
24 & Tekukur & Streptopelia hinensis & Columbidae & Buah dan Biji \\
& Toi/Nuri Pipit & Geoffroyus geoffroyi & Psittacidae & Buah \\
\hline
\end{tabular}

\section{Kerapatan/Kelimpahan Jenis Satwa Burung (Individu/Ha)}

Tabel. 4. Kerapatan (individu/ha) Hutan Lindung Gunung Sirimau

\begin{tabular}{|c|c|c|}
\hline No & Nama Jenis & Kerapatan (individu/ha) \\
\hline 1 & Burung Hujan & 23.59 \\
\hline 2 & Burung siang & 20.76 \\
\hline 3 & Cui & 56.15 \\
\hline 4 & Ekor Ikan/Layang layang api & 41.05 \\
\hline 5 & Elang Bondoi & 8.96 \\
\hline 6 & Kacamata Ambon & 11.32 \\
\hline 7 & Kakatua Hijau/Bayan & 6.13 \\
\hline 8 & Kakatua Putih Jambul Kuning & 5.66 \\
\hline 9 & Lawa lawa & 32.55 \\
\hline 10 & Maleo/gosong kaki merah & 20.76 \\
\hline 11 & Mata Merah & 219.39 \\
\hline 12 & Merpati Hutan & 43.41 \\
\hline 13 & Nuri Merah & 6.13 \\
\hline 14 & Nuri Raja & 15.57 \\
\hline 15 & Perkici dagu merah & 38.22 \\
\hline 16 & Perkici Pelangi & 33.97 \\
\hline 17 & Pombo & 6.13 \\
\hline 18 & Pombo Hijau & 17.93 \\
\hline 19 & Pombo putih & 14.63 \\
\hline 20 & Raja Udang & 35.39 \\
\hline 21 & Sesap Madu Sriganti & 46.24 \\
\hline 22 & Srigunting lencana & 45.29 \\
\hline 24 & Toi/Nuri Pipit Merah & 14.15 \\
\hline 25 & Total Kerapatan & 799.24 \\
\hline
\end{tabular}

Hasil penelitian yang disajikan pada Tabel 4 diatas menunjukan jumlah jenis burung yang terdapat pada lokasi hutan Lindung Gunung Sirimau, mempunyai total kerapatan untuk semua jenis burung adalah 799.24/ha. Dengan kerapatan jenis tertinggi didominasi oleh jenis burung Mata Merah (Aplonis motalica) seperti yang disajikan pada Gambar 1, dengan jumlah kerapatannya ,799.24/ha. 


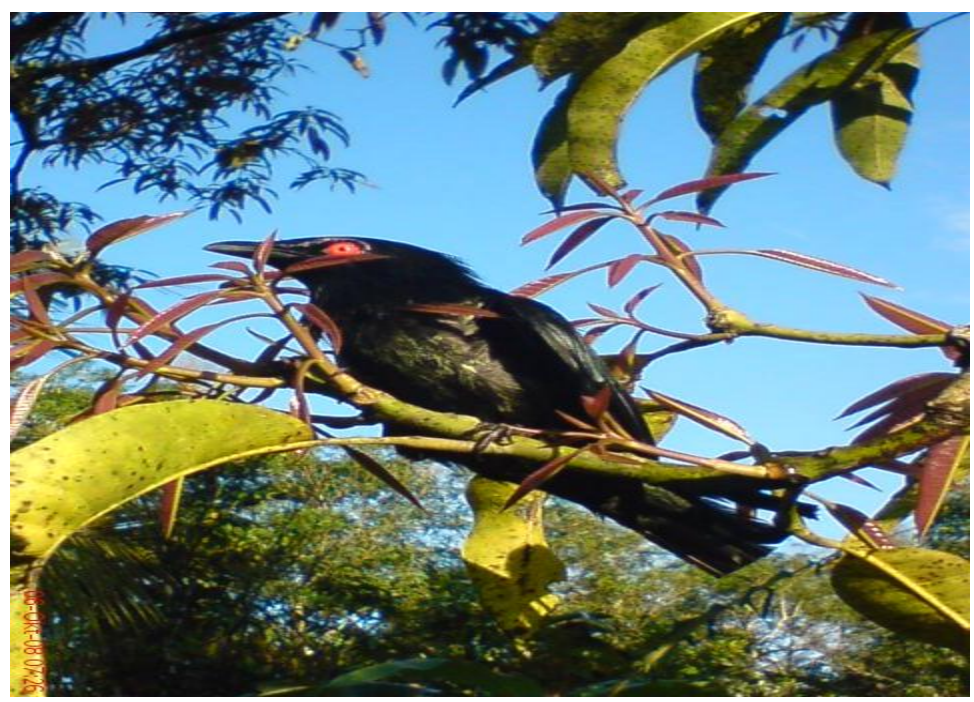

Gambar 1. jenis burung Mata Merah (Aplonis motalica)

\section{Lokasi hutan Lindung Gunung} Sirimau banyak sekali jenis buah buahan, yang pada waktu penelitian pohon - pohon tersebut sedang berbuah sehingga menjadi sumber pakan bagi jenis burung Mata Merah (Aplonis motalica) berupa buah dan biji - bijian yang dihasilkan oleh jenis vegetasi yang sedang berbuah, yang jumlahnya 16 jenis dari 32 jenis vegetasi yang ditemukan dalam tingkat pohon, atau sekitar $50 \%$ dari keseluruhan jenis vegetasi, selengkapnya dapat dilihat pada lampiran 11. Hal ini sesuai dengan pendapat Alikodra, 1990 yang menyatakan bahwa ketersediaan pakan yang tinggi memicu kehadiran jenis burung pada suatu tempat, kemudian disusul oleh jenis burung Cui (Collocalia esculenta) dengan nilai kerapatannya 56.15/ha, jenis burung ini mempunyai jenis atau sumber pakan adalah serangga, inilah yang menyebabkan jenis burung ini mempunyai kerapatan tertinggi kedua di hutan Lindung Gunung Sirimau, karena pada waktu musim buah banyak sekali buah - buahan yang jatuh dan busuk sehingga banyak sekali serangga yang memakan buah - buah tersebut yang jatuh dan membusuk, kemudian jenis burung Sesap Madu (Nectarinia jugalaris) dengan nilai kerapatannya 46.24/ha, karena pada saat penelitiann juga ada beberapa jenis vegetasi yang sedang dalam proses berbunga sehingga mengundang jenis burung ini untuk datang dan menghisap madu karena jenis burung ini mempunyai jenis pakan adalah penghisap madu, selanjutnya jenis burung Srigunting Lencana (Dicrurus bracteatus) dengan nilai kerapatannya adalah 45.29/ha, dengan jenis sumber pakannya adalah jenis serangga sehingga penyebab jenis burung ini sangat padat dilokasi Gunung Sirimau sudah dijelaskan seperti yang terjadi pada 
jenis jenis burung Cui (Collocalia esculenta). Sedangkan jenis burung yang mempunyai kerapatan terendah dilokasi hutan Lindung Gunung Sirimau adalah jenis burung Kakatua Putih Jambul Kuning (Cacatua galerita), dikarenakan jenis burung ini mempunyai tingkat daya reproduksi sangat kecil yang disebabkan oleh manusia, walaupun sumber pakannya sangat banyak pada lokasi Gunung Sirimau yaitu buah dan biji, penyebab lainnya juga dikarenakan bahwa jenis satwa burung ini habitatnya sulit untuk dekat dengan pemukiman manusia, serta menjadi buruan manusia yang dilakukan secara ilegal atau tersembunyi.

\section{Analisa Habitat di Hutan Lindung Gunung Sirimau}

Berdasarkan hasil penelitian di hutan lindung Gunung Sirimau ditemukan 34 jenis vegetasi yang terdiri dari 20 jenis Famil, selengkapnya dapat dilihat pada lampiran 8, sedangkan hasil analisa vegetasi menunjukan bahwa nilai kerapatan jenis yang tertinggi untuk tingkat pohon di hutan Lindung Gunung Sirimau ukuran petak 20 x 20 meter adalah jenis Agathis (Agathis dammara) dengan nilai kerapatan 135.00 pohon/ha, diikuti dengan jenis Meranti (Shorea Sp) nilai kerapatan 73.33 pohon/ha disusul dengan jenis
Kayu Merah (Augenis sp) dengan nilai kerapatan 61.67 pohon/ha. Untuk total keseluruhan jenis berjumlah 401.67 pohon/ha, seperti yang disajikan pada Gambar 2.

Untuk tingkat tiang hasil analisa menunjukan bahwa nilai kerapatan jenis yang tertinggi adalah jenis kayu Agathis (Agathis dammara) dengan nilai kerapatan 146.67 dan diikuti oleh jenis Kayu Merah (Augenis sp) dengan nilai kerapatan 70.00 pohon/ha, kemudian disusul dengan jenis Meranti (Shorea $S p$ ) dengan kerapatan 40.00 pohon/ha. Untuk total nilai kerapatan secara keseluruhan berjumlah 546.67 pohon/ha.

Untuk tingkat sapihan dengan ukuran $5 \times 5 \mathrm{~m}$, kerapatan yang tertinggi juga merupakan kayu Agathis (Agathis dammara) dengan nilai kerapatan 146.67 pohon/ha, diikuti dengan jenis Cengkih (Eugenia aromatica) dengan nilai kerapatan 146.67 pohon/ha, kemudian jenis Matoa (Pometia pinnata) dengan nilai kerapatan 120.00 pohon/ha, sedangkan total kerapatan secara keseluruah untuk tingkat sapihan adalah 680.00 pohon/ha. 


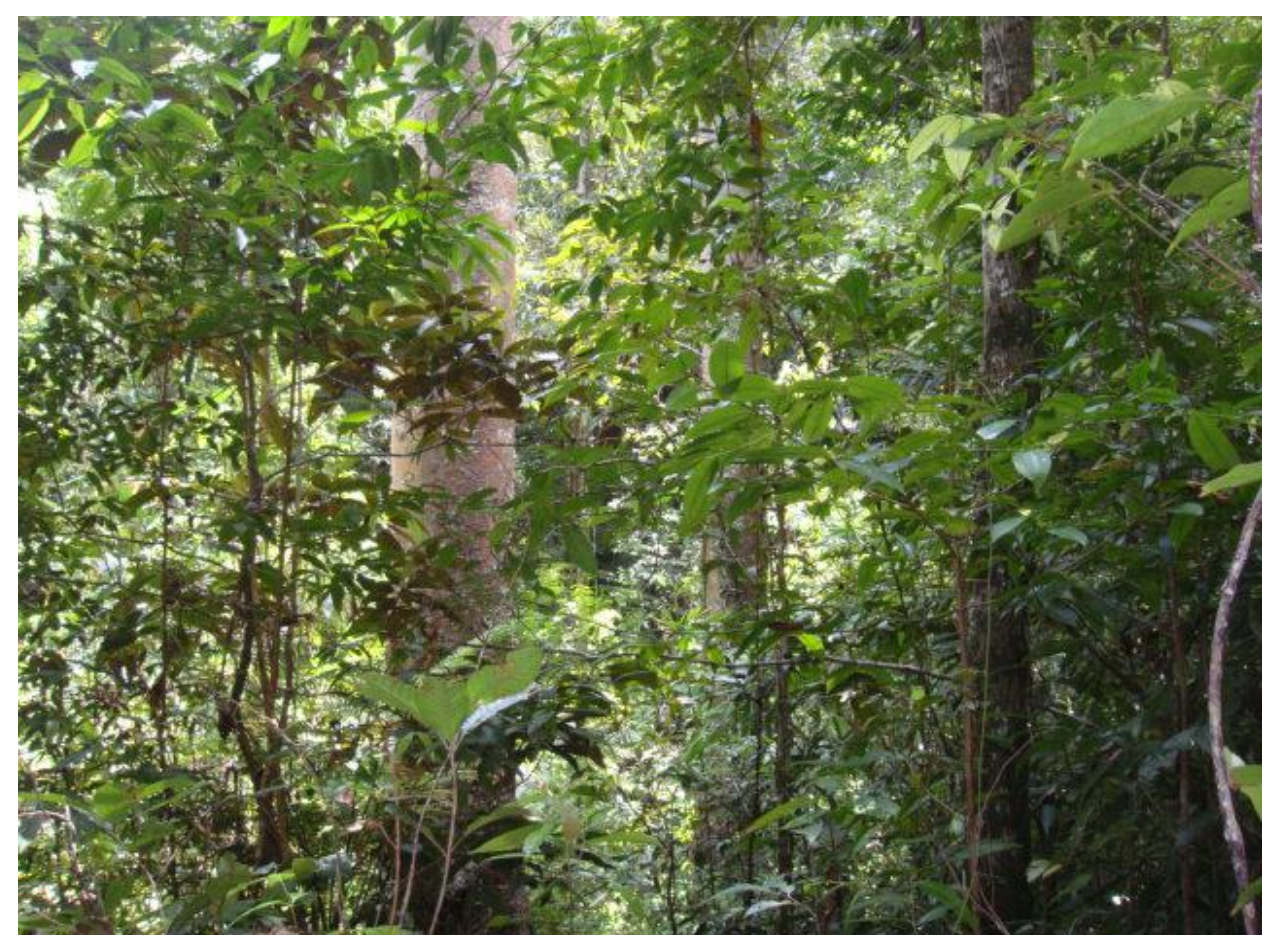

Gambar 2. Vegetasi di Hutan Lindung Gunung Sirimau

Sedangkan untuk tingkat semai pada petak berukururan $2 \times 2 \mathrm{~m}$ kerapatan jenis tertinggi terdiri dari jenis vegetasi Matoa (Pometia pinnata) dan Agathis (Agathis damara) dengan nilai kerapatan 833.33 pohon/ha, disusul dengan jenis Biroro dan Cengkih (Eugenia aromatica) yang masing - masing nilai kerapatan sama yaitu 750.00 pohon/ha untuk tiap jenis, kemudian diikuti dengan jenis Manggis Hutan (Gracinia) dan Pala Hutan (Horsfieldia sylfestris) nilai kerapatan sama untuk tiap jenis yaitu 500.00, sedangkan untuk total kerapatan secara keseluruhan untuk tingkat semai yaitu 6250.00 pohon/ha,
3.4 Nilai Frekwensi Vegetasi di Hutan Lindung Gunung Sirimau

Berdasarkan hasil analisa menunjukan bahwa frekwensi jenis yang tertinggi untuk tingkat pohon di hutan Lindung Gunung Sirimau ukuran petak $20 \times 20$ meter adalah jenis Agathis (Agathis dammara) dengan nilai frekwensi 0.90, diikuti dengan jenis Meranti (Shorea sp) dengan nilai frekwensi 0.87, disusul dengan jenis Kayu Merah (Augenis sp) dengan nilai frekwensi 0.77 .

Untuk tingkat tiang hasil analisa menunjukan bahwa nilai frekwensi jenis yang tertinggi adalah jenis Agathis (Agthis dammara) dengan nilai frekwensi 0.57, 
dan diikuti oleh jenis Kayu Merah (Augenis sp) dengan nilai frekwensi 0.37, kemudian disusul dengan jenis Meranti (Shorea sp) dengan nilai frekwensi 0.33, Untuk total nilai frekwensi secara keseluruhan berjumlah 3.63 .

Nilai INP, Dominansi dan Indeks Keanekaragaman Jenis Vegetasi di Hutan Lindung Gunung Sirimau.

Berdasarkan hasil penelitian di hutan Lindung Gunung Sirimau jumlah tanaman buah - buahan sebanyak $50 \%$ dari jenis vegetasi tanaman kehutanan diantaranya adalah : vegetasi yang mempunyai penguasaan jenis terbesar untuk tingkat pohon adalah jenis Agathis (Agathis adammara) dengan nilai INP 80.60 nilai dominansi 23,11 dengan indeks keanekaragaman jenisnya 0,153. Kemudian disusul oleh jenis Meranti (Shores sp) dengan jumlah INP 60.20 nilai dominansi 19,84 dan indeks keanekaragaman jenis 0,140. Dan jenis vegetasi yang ketiga didominasi oleh jenis Kayu Merah (Augenis sp) dengan nilai INP 44.56 nilai dominansi 11,78 dan indeks keanekaragaman jenisnya 0,123. Untuk total nilai INP secara keseluruhan di hutan Lindung Gunung Sirimau yaitu 300, Untuk jenis vegetasi tingkat tiang di hutan Lindung Gunung Sirimau jenis vegetasi yang mempunyai penguasaan jenis terbesar juga didominasi oleh jenis Agathis
(Agathis dammara) dengan jumlah nilai INP 66.71 sedangkan nilai dominansi 2,77 dan indeks keanekaragaman jenisnya adalah 0,145 diikuti oleh jenis Kayu Merah (Augenis sp) sedangkan nilai INPnya adalah 34,67 nilai dominansi 1,34 dan indeks keanekaragaman jenisnya adalah 0,108. Dan yang mempunyai penguasaan jenis yang terbesar yang ketiga adalah jenis Meranti (Shorea $s p$ ) dengan nilai dominansi adalah 0,94 sedangkan nilai INP-nya 24,85 dan indeks keanekaragaman jenisnya 0,090 serat nilai dominansinya adalah 0,94 . Untuk total secara keseluruhan pada pertumbuhan tingkat tiang nilai dominansi sebesar 10,59, INP 300 dan Indeks keanekaragaman jenisnya 1,222, kemudian untuk jenis vegetasi pada tingkat sapihan didominasi atau mempunyai penguasaan jenis tertinggi adalah jenis kayu Agathis (Agathis dammara) dengan nilai INP adalah 43.14 dan indeks keanekaragaman jenisnya adalah 0,14 disusul oleh jenis Cengkih (Eugenia aromatica) dengan nilai INP adalah 43,14 dan indeks keanekaragaman jenisnya 0,14 kemudian diikuti oleh jenis Matoa (Pometia pinnata) dengan nilai INPnya adalah 35,29 dan indeks keanekaragaman jenisnya adalah 0,13, sedangkan nilai total keseluruhan jenis untuk INP adalah 200, dan indeks keanekaragaman jenisnya 0,94 . Kemudian 
untuk analisa vegetasi tingkat semai penguasaan jenis tertinggi didominasi oleh jenis Agathis (Agathis dammara) dan Matoa (Pometia pinnata) diikuti oleh jenis Biroro dan Cengkih (Eugenia aromatica) dengan nilai INP 24,33 dan indeks keanekaragaman jenisnya adalah 0,111, dan menempati urutan ketiga adalah jenis vegetasi Pala Hutan (Horsfieldia sylfestris) dengan jumlah INP 16,22 dan indeks keanekaragaman jenisnya 0,088 sedangkan total nilai INP untuk tingkat Semai adalah 200 dan indeks keanekaragaman jenisnya adalah 1,150 .

\section{KESIMPULAN DAN SARAN}

\section{Kesimpulan}

1. Pada Hutan Lindung Gunung Sirimau yang paling terbanyak ditemukan jumlah jenis burung yaitu sebanyak 25 jenis dengan 14 familli,

2. Kerapatan jenis burung atau kelimpahan jenis burung di hutan lindung Gunung Sirimau adalah 799,24/ha, yang merupakan total keseluruhan.

3. Berdasarkan hasil penelitian di hutan Lindung Gunung Sirimau ditemukan 34 jenis vegetasi yang terdiri dari 20 jenis familli dengan indeks keanekaragaman jenisnya 1.081
Saran.

1. Untuk mengetahui faktor - faktor yang mempengaruhi keanekaragaman jenis burung maka sebaiknya dilakukan penelitian yang sama pada waktu musim hujan.

2. Berkaitan dengan keanekaragaman jenis burung maka perlu pengelolaan kawasan yang memperhatikan kelestarian keanekaragaman jenis burung dan keanekaragaman jenis vegetasi.

\section{DAFTAR PUSTAKA}

Alikodra, H.S. 1980. Konservasi Alam dan Pengelolaan Marga Satwa. Fakultas Pascasarjana, Jurusan Pengelolaan dan Sumberdaya Alam dan Lingkungan, IPB. Bogor.

Alikodra, H.S. 1980. Ekologi Banteng (Bos javanicus) di Taman Nasional Uning Kulon. Disertasi Doktor (tidak dipublikasikan). Fakultas Pasca Sarjana IPB. Bogor

Alikodra, 1990. Pengelolaan Satwa Liar Jilid 1. Departemen Pendidikan dan Kebudayaan. Direktorat Jendral Pendidikan Tinggi Pusat Antara
Universitas Ilmu Hayat Institut Pertanian Bogor.

Alikodra, 1994. Tropical Forest of Indonesia. Ministry of Forestry of Republic of Indonesia. Jakarta.

Anonim, 1995. Surat Keputusan Menteri Kehutanan Republik Indonesia No. 464/Kpts-II/1995. Tentang Tujuan Penetapan Penetapan Kawasan Hutan Lindung untuk Hutan Lindung Gunung Nona dan Hutan Lindung gunung Sirimau Kota Ambon.

Anonim, 1996. Surat Keputusan Menteri Kehutanan Republik Indonesia No. 
430/Kpts-II/1996. Tanggal 8 Desember 1996. Tentang Penetapan Kawasan Hutan Lindung untuk Hutan Lindung Gunung Nona dan Hutan Lindung gunung Sirimau Kota Ambon.

Anonim, 1999. Undang undang no 41 tahun 1999 tentang Kehutanan. Departeman Kehutanan

Anonim, 2009. Badan Meteorologi Dan Geofisika Kota Ambon.

Anselmus Jati, 1998. Kelimpahan dan Restribusi Burung Jenis - jenis Burung Berdasarkan Fragmentasi dan Stratifikasi Habitat Hutan Cagar Alam Langgaliru, Sumba. Thesis Program Pascasarjana Institut Pertanian Bogor.

Ajawaila, J.W.1996. Tinjauan Sosial Budaya Dusun. Pusat Studi Maluku. Universitas Pattimura Ambon.

Badarudin, E. (2006). Distribusi Jenis Satwa Burung Di Dusun Seri Kecamatan Sirimau.

Bailey, J.A. William, E, Ted. D. McKinney, 1974. The Wildlife Society. Washington.

Bailey, J.A. 1984. Principles of Wildlife Managemant. John Wiley dan Son, Inc. New York.

Bobour, M.G. Burk, J.H. and Pitts, W.D. 1980. Terrestrial Plant Ecology. The Benyamin/Cummings Publishing Company. California - USA.

Bruning, E.F. 1983. Vegetations Structure and Growth. In: Golley, F.B. (Editor). Tropical Rain forest Ecosystem: Structure and Function. Elsevier Sci. Publ.Company. New York.

Chistopheros. 1993. Analisis Vegetasi Hutan Rawa Gambut di Hutan Tropis Humida PT. Bintang Cikupada Botania Riau. Tesis (tidak dipublikasikan). Program Study Ilmu Kehutanan, Program Pascasarjana, Universitas Gajah Mada Yogyakarta.

Dasmann, R.F. 1964. Wildlife Bioligy. John Wiley dan Son, Inc. New York.

Desmukh, 1992. Ekologi dan Biologi Tropika. Terjemahan : Kuswata Keratawinata dan Sarkat Danimiharja. Edisi Peratama. Yayasan Obor Indonesia.

Djuwantoko, 1994. Perkembangan dan Status Bidang Konservasi Sumber Daya Hutan Serta Implemantasinya Dalam Pengelolaan Hutan Di Indonesia. Jurusan Konservasi Sumberdaya Hutan,
Fakultas Kehutanan Universitas Gajah Mada.

Djuwantoko, 1999. Potensi dan Alternatif Satwa Liar Sebagai Objek Ekowisata. Fakultas Kehutanan Universitas Gajah Mada.

Djuwantoko, 2000. Perspektif Ekosistem Konservasi Satwa Liar Di Hutan Produksi. Jurusan Konservasi Sumberdaya Hutan. Fakultas Kehutanan Universitas Gajah Mada.

Ewusie, J.Y. 1980. Elemant of Tropical Ecology. Heinenmenn Educ. Books Ltd. London.

Frans, J.J. 1997. Pola Dusun, Salah Satu Alternatif Pengelolaan Sumber Daya Hutan Di Maluku. Makalah Pada Seminar Pertanian Kepulauan 15-16 Desember 1997.

Hernowo, J.B. 1989. Satu Tinjauan Terhadap Keanekaragaman Jenis Burung Dan Peranannya Dalam Hutan Lindung Bukit Soeharto Kalimantan Timur. Media Konservasi 2.

Kaya, 2003. Dusun. Sistem Pengelolaan Lahan Tradisional. Dinas Kehutanan Provinsi Maluku.

Kissya, 1995. Sasi Amanharu, Ukiu, Document Treasures Of Lokal Culture. Jakarta Indonesia.

Laksono, 1995. Kearifan Tradisional dan Pelestraian Lingkungan Hidup Di Indonesia. Jurnal Analisis CSIS. Kebudayaan Kearifan Tradisional dan Pelestarian Lingkungan Tahun XXIV No.8 Tahun 1995.

Marsono, D. 1977. Deskripsi Vegetasi dan Tipe - tipe Vegetasi Tropika. Fakultas Kehutanan Universitas Gajah Mada.

Marsono, D. 2004. Konservasi Sumberdaya Alam dan Lingkungan Hidup. Sekolah Tinggi Teknik Lingkungan (STTL) Yokyakarta.

Mc. Arthur, R.H. and R. Levis, 1964. Compensation, Habitat and Character Disiplacement in Patchy. Proc. Nat. Acad. USA.

Moen, A.N. 1972. Wildlife Ecology, and Analitycal Approach. Cornell University. W.H. Freeman and Company. San Fransisco.

Richard, P.W. 1966. The Tropical Rain Forest: An Ecological Study. Canbridge at University Press. London. 
Reayaan, T. 2004. Struktur dan Komposisi Vegetasi Di Sekitar Hutan Lindung Gunung Nona. Skripsi Sarjana Universitas Pattimura Ambon.

Shaw. J.H. 1985. Introductions toWildlife Managemant. McGraw-Hil Book Co New York.

Sutjatnika, $1995 . \quad$ Melestarikan Keanekaragaman Hayati Indonesia. Pendekatan Daerah Burung Endemik. PHPA/Biordlife Internasional-Indonesia Programme.

Soerianegara, I. 1972. Ekologi Hutan Indonesia. Fakultas Kehutanan Institut Pertanian Bogor.
Soerianegara, I. 1996. Ekologi. Ekologisme dan Pengelolaan Sumberdaya Hutan. Jurusan Manajeman Hutan Fakultas Kehutanan Institut Pertanian Bogor.

Toni, H. 2003. Study Struktur dan Komposisi Vegetasi Bekas Tebangan Areal HPH PT. Sarmiento Parakantja Timber Kalteng. Tesis (tidak dipublikasikan). Program Studi Ilmu Kehutanan, Program Pascasarjana, Universitas Gajah Mada. Yogyakarta.

Wiratno, 2001. Berkaca Di Cermin Retak. Publikasi Forest Press, The Gibobon Foundation Indonesia, PILI - NGO Movement. 